\title{
An Academic Concept 'University' in a Linguistic Perception of German and Russian Students
}

\author{
Tatyana Y. Zaglyadkina ${ }^{1}$ \\ ${ }^{1}$ Kazan (Volga Region) Federal University, Kazan, Russia \\ Correspondence: Tatyana Zaglyadkina, Kazan (Volga Region) Federal University, 420008, Kazan, Kremlyovskaya \\ Street 18, Russia. E-mail: ztat45@yandex.ru
}

Received: June 2, 2015 Accepted: June 15, 2015 Online Published: June 29, 2015

doi:10.5539/jsd.v8n5p123 URL: http://dx.doi.org/10.5539/jsd.v8n5p123

\begin{abstract}
The relevance of the research problem is conditioned by a significant position, that take up the academic values based on their linguocultural concepts in the modern world, the intensification of Russian-German communication in the field of education generating the need to create a comparative academic conceptuary. The article is aimed at a determination of the comparative characteristics of the academic concept of 'university' in the German and Russian linguistic cultures. The leading method in carrying out of this study is linguistic experiment (free association experiment). As a result of the experiment, it was found that the list of associated attributes that make up the core of the concept of 'university' in the associative-verbal network of German-speaking and Russian-speaking subjects of academic activities, similar to, but different degree of relevance of these features. The only significant difference fixed in the association experiment is the presence in the German linguoculture associative relationship with the freedom of the student community and the absence of such a mutual relation in the perceptions of Russian students. The materials of the article may be useful in lexicology of the German and Russian languages, training courses on geography and linguocultural studies of Russia and Germany, in the practice of Russian-German academic communication.
\end{abstract}

Keywords: university, concept, higher education, free association experiment, lexeme

\section{Introduction}

\subsection{The Urgency of the Problem}

For more than two centuries, from the moment of its foundation, universities are places of education and training bright individuals, "the place with which the subsequent life of those people who provide the most significant impact on the spiritual landscape of our time is connected" (Kurennoy, 2003). The attractiveness of universities is in the freedom of thought and in the innovative ideas, in a rebellious spirit and in a peculiar vision of the future. The development of the modern university does not remain the same due to life is always on the move. The university as the top of the higher education system begins to take more and more leading positions in a society. The university is the real power, which is necessary to economy, army and political authority. Universities set the tone in the development of any country, become leaders in society (Nalyotova, 2005). The ways of the development of universities, which are directly connected with the intellectual life of society, were analyzed in the last century by such outstanding scientists as K. Jaspers (1980), J. Ortega y Gasset (1969), G. Carol (1988), J. Pelican (1992).

Universities are the pinnacle of higher education, they occupy a key position in the society. Economic growth and the country's competitiveness on the world stage also depends on the development of universities (Salmi, 2005).

In German and Russian linguocultures, the formation of universities was different. Despite the fact that the German and Russian cultures are parts of the global, cultural process, they carry the basic typological features, but as authentic cultures, they have its own peculiar features.

Linguocultural concepts based on academic values, particularly the concept 'university' which we consider, occupy the significant positions in the modern world. The intensification of Russian-German communication in sphere of education creates a need to shape a comparative academic conceptuary, which determines the urgency of this research. 


\subsection{The Hypothesis of Research}

There are academic conceptual spheres in Russian and German linguocultures, which are realized in a language system, a verbal associative network and in the process of communication. They have national characteristics and amenable to comparative linguistic study. The concept 'university', the concept of this research, belongs to the academic conceptual sphere.

\section{Materials and Methods}

\subsection{Research Tasks}

During the research the following tasks were being solved: 1) carrying out a free associative experiment. 2) definition of similarities and differences of the implementation of the concept 'university' in the linguistic perception of the subjects of academic activities in modern universities of Germany and Russia. 3) analysis of the results of the experiment.

\subsection{Theoretical and Empirical Methods}

The research bases on the principles of linguocultural approach. The following methods were used:

- Theoretical - analysis of literature, study and generalization of the experience of description of the concept, analysis, synthesis;

- Empirical - survey, a free associative experiment, which is a fairly effective method of studying the structure of various concepts.

\subsection{The Research Base}

200 respondents, students from different universities of Germany and Russia participated in the research. The experiment was carried out in writing by questionnaires. The total number of surveys was 200 . As stimuli-words respondents were offered lexemes, which are the names of these concepts. While processing received data, associations, similar in the sense were generalized.

\section{Results}

\subsection{The Realization of the Concept "University» in the Linguistic Perception of German Students}

The analysis of the questionnaire discovered that 54 German students have single reactions to a stimulus word 'student'. 15 respondents discovered 2 reactions each. The same quantity of respondents showed 3 reactions each, 7 respondents - 4 reactions each, 5 respondents - 5 reactions each, 1 respondent - 6 reactions, 1 respondent - 8 reactions and 2 respondents -9 reactions each. The total number of reactions was 214 .

On the assumption of the data in table 1 we can see that the German students have reactions associated with the concept of 'Studium/Lernen' (study, to study) on the first position $(18,6 \%)$. The second position is taken by the associations with the concept of "student" $(8,8 \%)$, the third position is taken by the concept of 'Bildung' (education) $(7,4 \%)$. On the fourth position there are reactions associated with the concept of 'Vorlesung' (lecture) and 'studiengebühren' (tuition) (6\% each). And the fifth position is closed be reactions associated with the concept of 'Hörsaal' (lecture hall) (3,7\%).

'University' for the German students is associated with the process of studying which students realize in order to get education. And to get education you need to attend the lectures. It means that the perception of university matches the classic model of getting education. The presence of the associations with the tuition (studiengebühren) a little doesn't match the general scheme of the functioning of the university as the educational institution.

In the process of analyzing the data of the associative experiment the following associative groups were distinguished:

- educational activity (63 reactions) (studium (education) - 9, wissen (knowledge) - 3, vermittlungvon wissen (supply of knowledge) - 2, studiengang (educational process) - 1, klausuren (tests) - 1, vorlesungen (lectures) - 8, Prüfungen (exams) - 3, lernen (to study) - 18, Abitur (abitur) - 1, semester (semester) - 1, Hörsaal (lecture hall) 6, lange Unterrichtszeiten (long duration of the lectures) - 1, Fächer (subjects) - 1, Fakultät (faculty) - 1, Bibliothek (library) - 1, Bücherei (library) - 2, Lehre (teaching) - 5);

- freedom of learning (5 reactions) (Freiheit (freedom) - 1, Freiheit der Lehre (freedom of learning) - 1, scheinbave politische Unabhändigkeit (apparent political independence) - 1);

- researching activities (5 reactions) (offene Forschung (open research) - 1, forschen (to research) - 1, forschung (research) - 1, Wissenschaft (science) - 1, Datenreichtum (richness of the information) - 1); 
- opportunities (5 reactions) (entfaltungsmöglichkeiten (the opportunity to open up) - 1, intellektuelle Betätigung (intellectual activity) - 1, selbständigkeit (self-dependence) - 2, weiterführende schule (school that gives an opportunity to move on) - 1);

- spare time (3 reactions) (Party (party) - 1, Freizeit (spare time) - 1, studentenleben (student's life) - 1).

\subsection{The Realization of the Concept 'University' in the Linguistic Perception of Russian Students}

After processing the survey data of Russian respondents it was found that 25 people have given one reaction to the word- impetus, seven respondents- two each, six- three each, twelve- four each, seven-five each, eight- six each, four-seven each, eight- six each, four-seven each and one respondent gave eight reactions. The total number of reactions is 235 .

On the basis of material shown in table №1, we see that in first position among Russian students is taken by associations with the words 'session', 'periods' (11\%). The second position is taken by the association related with the concept 'education' $(6,8 \%)$. In the third position there are three associations: 'knowledge', 'teachers', 'education' $(6,3 \%)$. In the fourth position there are associations with the words 'lecture', 'dining room' $(4,2 \%)$.

Based on the results of the experiment among Russian students, we can distinguish the following associative groups:

- academic activity (83 reactions) (studies-10, credits- 5, exams- 9, knowledge-10, education- 4 , periods-10, schedule-2, session- 13 , lecture- 8 , seminar- 4 , study-2, lessons-1, lecture-room- 3 , marks- 5 , coursework-1, language laboratory-1, grades-1);

- place of study (22 reactions ) (institute- 2, VISTEC-5, teacher training University- 1, VSU-2, VAPS-1, MSU-1, Oxford-1, high school- 1, buildings - 2, large building - 1, a huge building - 1, a house of knowledge $1)$;

- interest in study (16 reactions) ( new friends-1, new people-1, new circle of friends, new city-1, interesting objects-2, here it is very interesting-1, learning is the eye of the mind- 1 , relations- 2 , prestige- 1 , good prospect 1 , perspective work in the future- 2 , a path in life- 2 );

- student life (11 reactions ) ( dining room- 8, library- 2, dormitory- 1);

- learning difficulties (10 reactions) (hunger-1, getting not enough sleep-1, headache- 1 , the inability to learn all things- 1 , no personal life- 1 , to get up early- 1 , a lot of time to practice- 1 , torments- 1 , difficult work, but at the same time very funny-1);

- lecturing staff ( 10 reactions ) ( teachers- 10 );

- education process management (5 reactions ) (dean`s office- 3 , dean- 1, chair- 1 ).

For Russian students "university" means a learning process, subject to the control of knowledge and directed to education.

3.3 Similarities and Differences in the Realization of the Concept "University" in Language Perception of German and Russian Students

Let's compare the data of the associational experiment of German and Russian students by the first five positions. Comparative data are given in Table 1.

Table 1. The reaction of German and Russian students on the stimulus word 'university' in comparison

\begin{tabular}{cccc}
\hline Reactions of German students & Percentage ratio & Reactions of Russian students & Percentage ratio \\
\hline 1. Studium/lernen & $18,6 \%$ & 1. Examination period/classes & $11 \%$ \\
2. Student & $8,8 \%$ & 2. Education & $6,8 \%$ \\
3. Bildung & $7,4 \%$ & 3. Knowledge/ teachers/study & $6,3 \%$ \\
4.Vorlesung/ Studiengebühren & $6 \%$ & 4. Students/ examinations & $5,9 \%$ \\
5. Hörsaal & $3,7 \%$ & 5. Lecture/canteen & $4,2 \%$ \\
\hline
\end{tabular}

The core of the concept 'university' of German and Russian students is exemplarily similar, but the arrangement of the components on the degree of importance is different. The most important thing for German students is study (the 1st position). On the 1st position of Russian students are associations connected with such words as 
'examination period', 'classes', that is not only study, but also knowledge control.

Association 'Studenten' takes the 2nd place of German students, whereas it holds the 4th position of Russian students. Associations connected with the concept 'education' (Bildung) are a little lower at German students, on the 3rd position, whereas there are on the 2nd position of the Russian students. Respectively, on the 4th place of the German students are associations connected with word 'Vorlesung' (lecture), for Russians such association are on the 5 th position.

In the notion about universities of Russian and German students 4 components are included - study, student, education and lecture. Associative relations of the concept 'Universitat' are close enough, with 6 associations are on 5 positions. The idea of university which was formed in German students minds is relevant to the idea, historically based in a society. Russian students have 10 associations on 5 positions. Their idea of university is vague. The university is not associated straight with the place of getting knowledge and degree. There are such associations as session, exams and canteen. In other words, although generally true purpose of university is teaching, for Russian students it is control on the first place.

The amount of associative groups formed during data processing is equal - 7 for each side. Only two associative groups from all singled out - studying and teachers group - are similar for both Russian and German students. It is undoubtfully stemmed from university functions. Further groups are becoming different. German students appreciate exploratory activity, the opportunity to reveal your personality and also the freedom of studying. It is not accidentally, because historically universities in German have been functioning on the basis of Humbolt's pattern of education development, according to which free science, equality of teaching and explorations form university activity. Associations, related to spending spare time form very small group. The small amount of such associations is because university is a place of getting knowledge, not having fun.

There are no associative groups related to the freedom of teaching and scientific activity among Russian students' reactions. It is stemmed by different historical development of both Russian and German universities. In Germany universities historically were established as a result of a fight between religious power and seculiar power, while in Russia they were established by supreme power so there were no possibility of a free research and education.

The second in size association among the reactions of Russian students is a 'place of education' which involves mostly various higher education institutions. The interesting thing is that Russian students don't have an objective perception of the university, it is separated into a smaller parts. An association related to the eagerness of learning in the university is also strong. It points to the fact that the Russian higher education's prestige lost in 90s is now on the rise. Associations 'students' chores' and 'learning difficulties' were not shown by German students. These reactions found their place in the perception of Russian students as there is still an unsolved problem with an accommodation and food among students. The last mentioned association seems interesting because it demonstrates another side of education. In our opinion, it is a strong argument in a discussion relating the confirmation of educational schedule in higher education institutions. Apparently, these schedules have not been thought through yet and don't represent the contemporary realities of educational and disciplinal processes.

Therefore, German students associate the lexeme 'university' with gaining the education during the learning. Russian students associate the lexeme "university" with a learning process for getting the education, in which the control of knowledge plays a huge role.

\section{Discussions}

It should be noted that the use of free association experiment in the practice of modern linguistic-cultural research beyond doubt. Analysis of the concept of 'university' showed that in the minds of the subjects of academic activities, which include student academic community, the structure of the concept is virtually identical. The concept has a similar set of associative features, but a different degree of their relevance. Despite the fact that the German and Russian universities were formed in completely different historical, political and economic conditions, they are characterized by the presence of similar academic concept sphere; one of the key is the concept of 'university.' This statement is quite compatible with the values of the modern globalized society.

Research of different kinds of concepts devoted a huge amount of work and approaches to the study of the concept are different. Concept is one of the most diversely interpreted terms. The domestic linguistic-cultural studies, conceptual direction occupy an important place and are interdisciplinary in nature. In this connection, it should be highlighted the contribution of the following authors in the study of the concept: Y.S. Stepanov (1997), A.Vezhbitskaya (2001), N.D. Arutyunova (1999), J.D. Apresyan (1995), V.I. Karasik (2002) G.G.Slyshkin (2004) and others. 
Reviewed academic concept of 'university' was not examined before. The scientific novelty of this study is to examine the implementation of this concept in the minds of the subjects of the professional language of academic activities and obtaining the relevant results that allow us to summarize the following.

\section{Conclusion}

The core of the concept 'university' in the association and verbal system of German and Russian-speaking subjects of academic activities includes the following elements:

- 'study', 'teaching staff', 'presence or absence of freedom', 'science', 'opportunities and prospectives' of the German students;

- 'study', students chores','novelty and interest','opportunities and prospectives', 'difficulties and problems','teaching staff', 'administration of the university' of the Russian students. As it was mentioned above a set of associative features is similar, the difference is in the degree of their relevance. The only significant difference fixed in the experiment is the presense of associative link between students' society and freedom in the German linguoculture and absence of such link in the perception of Russian students.

\section{Recommendations}

Materials of the article may be useful in the academic courses on lexicology of Russian and German, in courses on country studies and linguistic country studies of Germany and Russia, in the practice of Russian and german academic communication.

\section{Acknowledgments}

The work is performed according to the Russian Government Program of Competitive Growth of Kazan Federal University.

\section{References}

Apresyan, J. D. (1995). Selected works. Lexical semantics. Moscow.

Arutyunova, N. D. (1999). The language and world of man. Moscow.

Carall, J. (1988). The Post-Humanist University. Three Theses. The Salisbury Review, 2, 20-25.

Jaspers, K. (1980). The Idea of the University. London.

Karasik, V. I. (2002). Linguistic circle: personality, concepts, discourse. Volgograd.

Kurennoy, V. (2003). Discussion on the university. Domestic proceedings, 6(15). Retrieved from http://strana-oz.ru/print.php?type=article \&id=720\&numid $=15$

Nalyotova, I. V. (2005). Diversification of the higher education: a challenge to universities. Higher education in Russia, 5.

Ortega, Y. C. (1969). Mission of the University. Boston.

Pelican, J. (1992). The Idea of the University. A Reexamination. New Haven and London.

Salmi, J. (2009). The Challenge of Establishing World-Class Universities. 3-rd WCU Conference. Shanghai. http://dx.doi.org/10.1596/978-0-8213-7865-6

Slyshkin, G. G. (2004). Linguocultural concepts and metaconcepts. Volgograd.

Stepanoov, U. S. (1997). Constants: A dictionary of Russian culture. Moscow.

Vezhbitskaya, A. (2001). Understanding of cultures through key words. Moscow.

\section{Copyrights}

Copyright for this article is retained by the author(s), with first publication rights granted to the journal.

This is an open-access article distributed under the terms and conditions of the Creative Commons Attribution license (http://creativecommons.org/licenses/by/3.0/). 